\title{
Rancang Bangun Alat Monitoring Kerusakan Lampu Penerangan Jalan Umum Berbasis Mikrokontroler dengan Notifikasi SMS
}

\author{
(Design and Development of Damage Monitoring Tools for Public Street Lighting \\ with Microcontroller and SMS Notification)
}

\author{
I Gede Andhika Putra, Anak Agung Ngurah Amrita, I Made Arsa Suyadnya \\ Program Studi Teknik Elektro, Fakultas Teknik, Universitas Udayana \\ Jl. Kampus Bukit Jimbaran, Bali, INDONESIA \\ Email: andhika.putra02@yahoo.com,ngr_amrita@ee.unud.ac.id, arsa.suyadnya@unud.ac.id
}

\begin{abstract}
Public street lighting is part of a complementary road that serves to illuminate streets at night. Public street lighting lamps are generally operated throughout the night until early morning continuously without equipped tools that monitor conditions. The non-functioning of public street lighting is often not known by officers. In this study, a microcontroller-based damage monitoring tools was built with an SMS-based notification service. This tool is suitable to be implemented to monitor the state of public street lighting because it can monitor the state of lights during the day, lights go out and dim at night, and also can check the state of the lights by sending commands via SMS service. By sending the "CEK LPJU" command via SMS, the monitoring tool will give a reply regarding the state of the public street lighting. In addition, the monitoring tool will automatically send SMS regarding disturbances that occur in public street lighting.
\end{abstract}

Key words: public street lighting, monitoring tools, SMS, microcontroller

\section{PEndahuluan}

Lampu penerangan jalan umum (LPJU) merupakan insfrastruktur vital bagi kehidupan masyarakat di malam hari, karena LPJU selain berfungsi untuk menerangi ruasruas jalan di malam hari, juga mempunyai fungsi lain seperti fungsi keamanan, fungsi ekonomi, dan fungsi keindahan. Fungsi keamanan, berkaitan dengan fungsinya untuk melancarkan pengendara jalan umum terutama pada malam hari, dimana pengguna jalan membutuhkan penerangan dengan cahaya tertentu untuk menghindari terjadinya kecelakaan dan mengurangi resiko tindak kriminal. Fungsi ekonomi, berkaitan dengan penerangan di jalan umum yang akan membantu kelancaraan distribusi barang pada malam hari. Sedangkan fungsi keindahan, dipengaruhi oleh pengaturan letak dan desain lampu penerangan jalan sehingga dapat memperindah wajah kota di malam hari.

Pemantauannya akan menjadi lebih kompleks ketika jumlah LPJU semakin banyak dan meliputi wilayah yang luas, sedangkan tenaga teknis yang bertugas melakukan pemeliharaan jumlahnya terbatas sehingga tidak berfungsinya LPJU justru sering tidak diketahui dan ditindaklanjuti setelah munculnya pengaduan dari masyarakat. Permasalahan berikutnya muncul ketika penyebab tidak berfungsinya LPJU bukan disebabkan karena kerusakan lampu. Proses ini juga akan memerlukan waktu yang cukup lama sampai ditemukan penyebab kerusakannya. Sehingga untuk mempermudah pekerjaan petugas maka diperlukan alat untuk memonitoring kerusakan LPJU.

Dalam membangun alat monitoring kerusakan LPJU dapat memanfaatkan sensor LDR (Light Dependent Resistor) sebagai indikator pendeteksi cahaya dan memanfaatkan layanan pesan singkat/SMS sebagai notifikasi untuk mengetahui apakah LPJU keadaan hidup dan mati [1]. Penggunaan sensor LDR ini hanya dapat mendeteksi kondisi lampu dalam keadaan hidup atau mati, namun belum dapat mendeteksi kerusakan dari aspek lainnya. Untuk mendeteksi kerusakan karena putusnya arus listrik diperlukan sensor arus dan tegangan. Seperti pada penelitian [2] memanfaatkan sensor arus tipe ACS712 untuk mengetahui nilai arus yang mengalir pada jaringan pembangkit terbarukan dan sensor tegangan dengan tipe transformator step down $220 \mathrm{~V}$ ke $5 \mathrm{~V}$ untuk mengetahui nilai tegangan yang dibangkitkan oleh pembangkit terbarukan.

Pada penelitian ini dibangun sebuah alat monitoring kerusakan LPJU dengan memanfaatkan sensor LDR sebagai indikator untuk mengetahui terjadinya gangguan pada lampu, sensor arus SCT013-030 untuk mengetahui besaran arus yang mengalir pada LPJU, dan sensor tegangan yang digunakan indikator untuk mengetahui putusnya sumber tegangan. Selain itu, alat monitoring ini diintegrasikan dengan sistem notifikasi berbasis SMS. Petugas LPJU dapat melakukan pengecekan keadaan LPJU dengan mengirimkan pesan singkat/SMS (Short Message Service) ke alat monitoring. Dengan adanya alat monitoring ini diharapkan dapat memudahkan petugas 
dalam melaksanakan tugasnya seperti mengetahui terjadinya gangguan termasuk mempersingkat waktu untuk mencari penyebab tidak berfungsinya LPJU.

\section{TINJAUAN PUSTAKA}

\section{A. Arduino}

Arduino adalah papan rangkaian elektronik open soure yang di dalamnya terdapat komponen utama, yaitu sebuah chip mikrokontroler dengan jenis AVR dan softwarenya memiliki bahasa pemrograman sendiri. Mikrokotroler itu sendiri adalah chip atau IC (Integrated Circuit) yang bisa diprogram menggunakan komputer. Jadi mikrokontroler bertugas sebagai otak yang mengendalikan input, proses, dan output sebuah rangkaian elektronik [3]. Modul Arduino UNO R3 ditunjukkan pada Gambar 1.

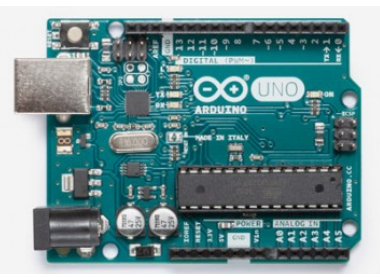

Gambar 1. Arduino

\section{B. Current Transformer (CT)}

Current Transformer (CT) adalah suatu peralatan yang mengubah besaran arus dari besar ke kecil ataupun sebaliknya sesuai dengan kebutuhan yang diperlukan. CT umumnya selain digunakan sebagai media pembacaan juga digunakan dalam sistem proteksi tenaga listrik. Pada penelitian ini menggunakan sensor arus tipe SCT013-030, cara kerja dari sensor arus SCT013-030 ini menggunakan konsep kinerja trafo arus (CT). Sensor SCT013-030 ditunjukkan pada Gambar 2.

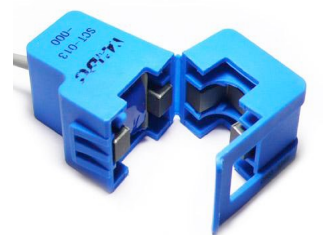

Gambar 2. Bentuk fisik Sensor Arus SCT-013-030

\section{Transformator}

Transformator digunakan untuk menaikan atau menurunkan tegangan serta mengatur impedansi dalam sistem daya dan elektronik. Transformator terdiri dari susunan gandengan lebih dari satu kumparan yang digulungkan pada suatu inti besi. Dalam rangkaian yang mempunyai gandengan bersama, suatu arus yang yang berubah menurut waktu dalam salah satu kumparannya akan menghasikan tegangan imbas pada kumparan lain. Pada penelitian ini menggunakan transformator step down $230 \mathrm{~V}$ ke $9 \mathrm{~V}$ untuk rangkaian sensor tegangan [4]. Transformator ditunjukkan pada Gambar 3.

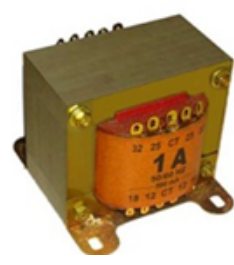

Gambar 3. Potensial Transformator

\section{Sensor Cahaya}

Photoresistor atau yang juga dikenal sebagai LDR (Light Dependent Resistor) merupakan komponen resistor variabel yang nilai hambatannya berubah karena faktor intensitas cahaya. Jika intensitas cahaya yang mengenai permukaan sensor cukup terang, nilai hambatannya menjadi rendah, kira-kira $1 \mathrm{~K} \Omega$ dan bila LDR diletakan pada tempat yang gelap, maka nilai hambatannya menjadi tinggi hingga mencapai $10 \mathrm{M} \Omega$ [5]. Bentuk fisik LDR ditunjukkan pada Gambar 4.

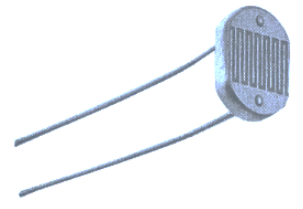

Gambar 4. Bentuk fisik LDR

\section{E. Modul IComSat v1.1-SIM900 GSM/GPRS Shield for Arduino \\ Modul IComSat v1.1-SIM900 GSM/GPRS Shield for} Arduino adalah modul GSM untuk Arduino yang berperan untuk melakukan fungsi pengiriman SMS [6]. Modul GSM ini berfungsi untuk mengirim dan menerima pesan SMS antar pengguna mobile phone. Modul GSM ini dapat dikontrol dengan menggunakan sebuah program. Dengan serangkaian perintah yang dibuat menggunakan bahasa pemrograman, instruksi-instruksi khusus dikirimkan dari komputer kepada alat ini melalui kabel data yang dihubungkan langsung ke terminal datanya [7]. Modul IComSat v1.1 SIM900 GSM/GPRS Shield for Arduino ditunjukkan pada Gambar 5.

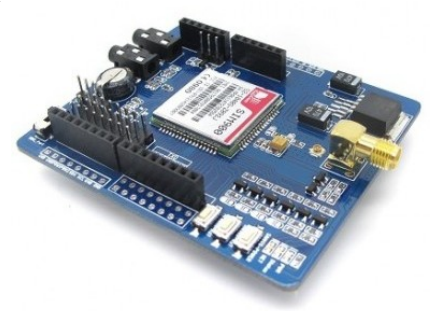

Gambar 5. Modul IComSat v1.1 SIM900 GSM/GPRS Shield for Arduino

\section{F. Real Time Clock (RTC)}

Pada sistem digital, digunakan sebuah komponen khusus yang disebut RTC (Real Time Clock) dalam bentuk chip atau IC untuk menjaga informasi waktu. Kebanyakan chip RTC dilengkapi dengan RAM (Random Access Memory) agar dapat menyimpan data yang dibutukan oleh sistem utama. Salah satu chip RTC yang sering digunakan 
adalah IC DS1307 [5]. IC DS1307 ditunjukkan pada Gambar 6.

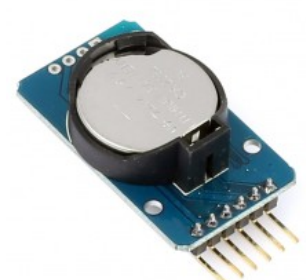

Gambar 6. Modul RTC (Real Time Clock

\section{G. $\quad$ LCD (Liquid Crystal Display)}

LCD (Liquid Cristal Display) atau yang sering disingkat dengan LCD adalah suatu jenis display elektronik sebagai media tampilan yang menggunakan kristal cair sebagai tampilan utama. LCD cukup popular digunakan untuk menampikan teks, angka, dan simbol. LCD karakter memiliki beberapa ukuran jumlah baris dan kolomnya, antara lain $8 \times 2,16 \times 2,20 \times 2,20 \times 4$, dan sebagainya [5]. Modul LCD ditunjukkan pada Gambar 7.

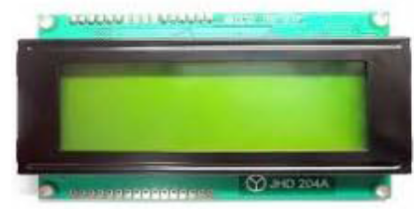

Gambar 7. LCD (Liquid Crystal Display)

\section{DeSAIN SISTEM}

\section{A. Pemodelan Umum Sistem}

Pemodelan umum sistem merupakan suatu proses awal untuk membangun atau merancang sebuah alat. Pada pemodelan sistem yang dirancang memasang 3 titik penempatan sensor yaitu :

1. Pada output meteran PLN dipasang sensor arus untuk mengetahui besaran nilai arus yang mengalir pada sistem LPJU dan sensor tegangan untuk mengetahui nilai tegangan yang mengalir pada output meteran PLN dan memastikan apakah ada atau tidak suplai tegangan dari PLN.

2. Pada input lampu dipasang sensor tegangan untuk mengetahui apakah sudah mengalir tegangannya sampai pada input LPJU.

3. Pada lampu dipasang sensor LDR ini nantinya akan memantau keadaan lampu apakah lampu tersebut dalam kondisi terang, padam, dan mati.

Sistem kerja dari alat ini, petugas akan mendapatkan notifikasi pesan SMS apabila terjadi gangguan pada LPJU seperti lampu padam dan lampu redup. Apabila user/petugas melakukan pengecekan dapat langsung mengirimkan SMS sesuai format yang diprogramkan pada alat monitoring kerusakan LPJU. Alat monitoring akan memverifikasi format dari SMS yang diterima, dan apabila format valid maka alat monitoring akan mengirimkan notifikasi SMS ke user/petugas yang berisi kondisi dari LPJU. Blok pemodelan sistem ditunjukkan pada Gambar 8.

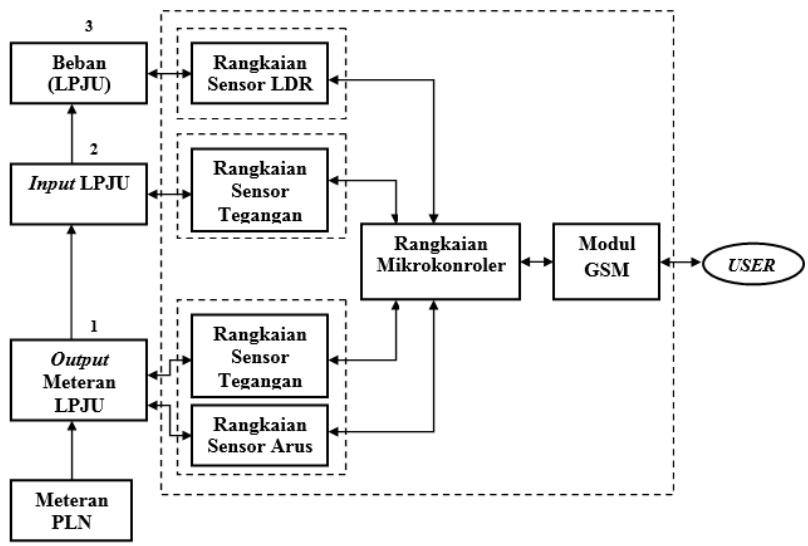

Gambar 8. Blok pemodelan sistem.

\section{B. Perancangan Perangkat Keras}

Perancangan perangkat keras yang digambarkan dalam diagram blok seperti pada Gambar 9 .

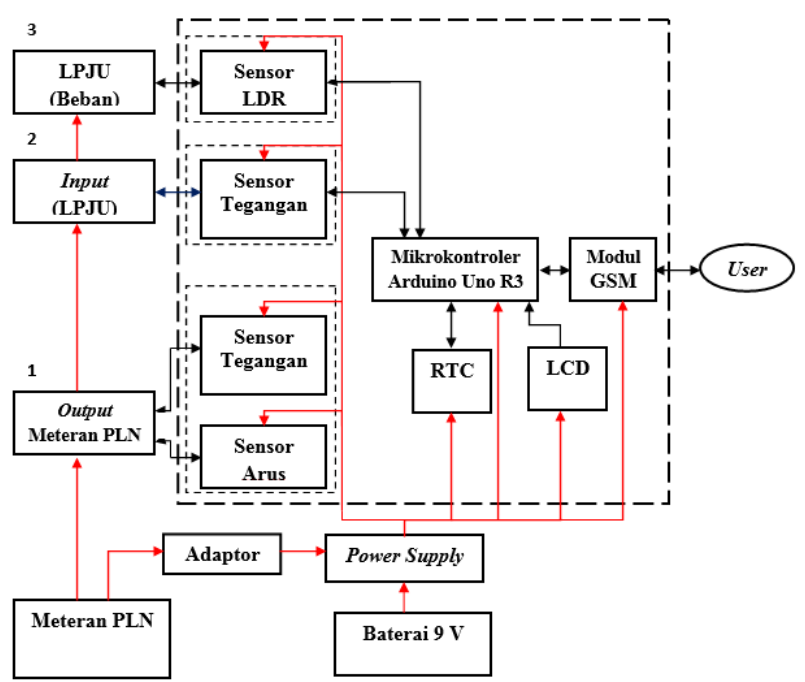

Gambar 9. Blok diagram rangkaian

Seperti pada gambar 9 perancangan perangkat keras sistem monitoring kerusakan LPJU terbagi menjadi beberapa bagian, yaitu :

1. Perancangan rangkaian power supply

2. Perancangan rangkaian sensor arus

3. Perancangan rangkaian sensor tegangan

4. Perancangan rangkaian sensor LDR

5. Perancangan rangkaian RTC

6. Perancangan rangkaian LCD

7. Perancangan rangkaian mikrokontroler

\section{Perancangan Perangkat Lunak (Software)}

Perancangan perangkat lunak pada rancang bangun alat untuk monitoring kerusakan LPJU berbasis mikrokontroler dengan notifikasi SMS dengan menggunakan software bawaan dari arduino yaitu Arduino IDE (Integrated Development Environment). Terdapat 2 pemodelan sistem dari perancangan perangkat lunak 
seperti diagram alir pengiriman notifikasi SMS ke petugas (user) dan diagram alir pengecekan LPJU.

\section{C.1 Diagram Alir Pengiriman Notifikasi SMS ke Petugas (User)}

Diagram alir dari pengiriman notifikasi SMS ke petugas bila terjadi kerusakan LPJU ditunjukkan seperti Gambar 10.

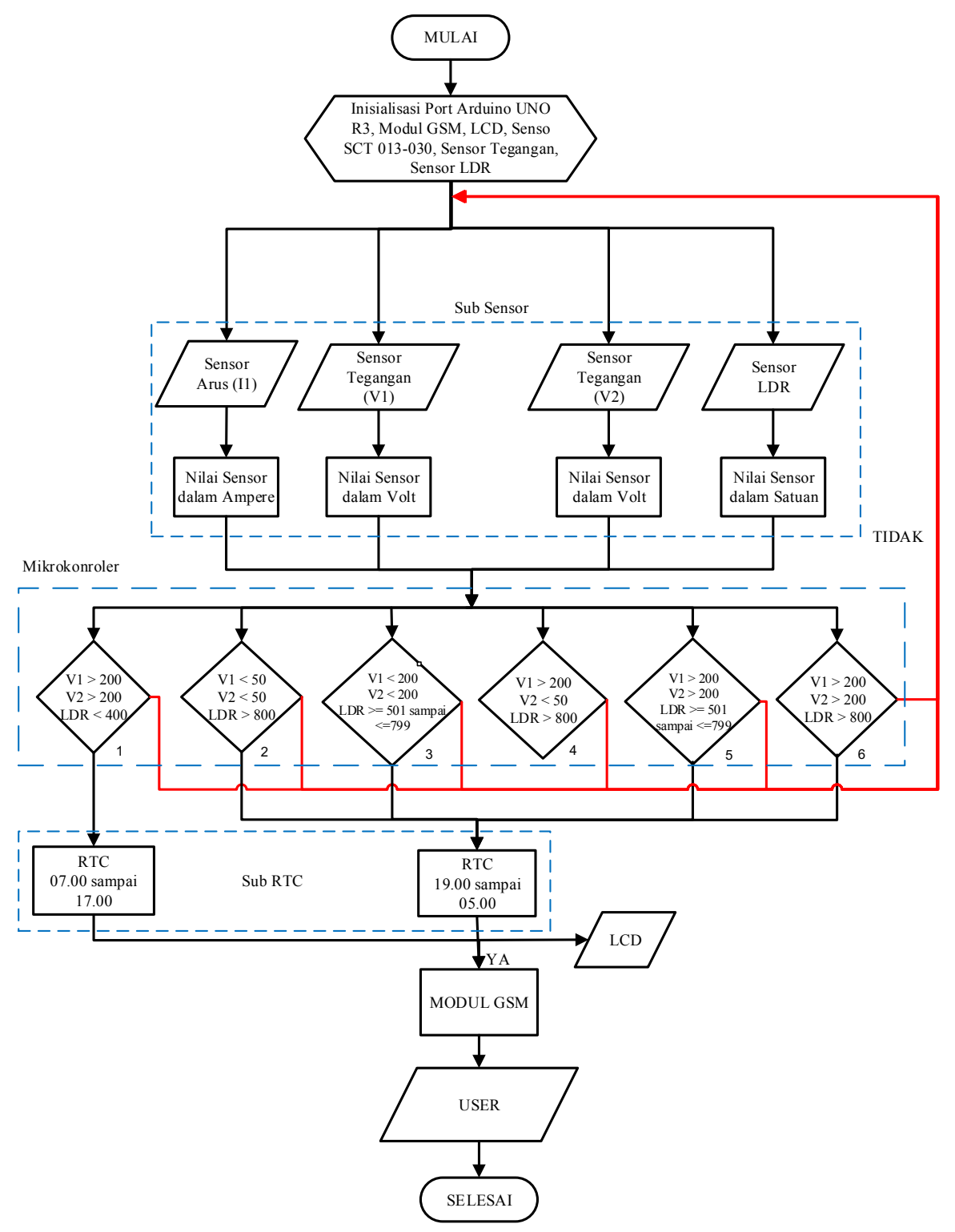

Gambar 10. Diagram alir pengiriman notifikasi SMS ke petugas (user).

Dari gambar 10 dapat dilihat alur program utama dari rancang bangun alat monitoring kerusakan LPJU dengan pengiriman notifikasi SMS ke petugas :

1. Masukan inisialisasi port variabel sensor serta komponen lain dan variabel yang digunakan dalam konfigurasi pada mikrokontroler.

2. Sub RTC ini nanti yang akan menginformasikan modul GSM dalam mengirim SMS ke user. Pada RTC yang diatur adalah detik, menit, jam, hari, bulan, dan tahun.
3. Sub pembacaan nilai sensor arus, tegangan, dan LDR ini akan menggolah output dari nilai sensor yang nantinya terhubung ke mikrokontroler.

4. Pada mikrokontroler, jika nilai yang dibaca oleh sensor arus, sensor tegangan, dan sensor LDR berlogika seperti :

a. Jika logika 1 yang dibaca maka modul GSM akan memberikan notifikasi ke user dengan SMS : "Info : LAMPU MENYALA".

b. Jika logika 2 yang dibaca maka modul GSM akan memberikan notifikasi ke user dengan SMS : 
"Info : LAMPU MATI (SUMBER PLN MATI)",

c. Jika logika 3 yang dibaca maka modul GSM akan memberikan notifikasi ke user dengan SMS : "Info : LAMPU REDUP (DROP TEGANGAN)",

d. Jika logika 4 yang dibaca maka modul GSM akan memberikan notifikasi ke user dengan SMS: "Info: LAMPU MATI (CEK PENGKABELAN)",

e. Jika logika 5 yang dibaca maka modul GSM akan memberikan notifikasi ke user dengan SMS : "Info : LAMPU REDUP (CEK LAMPU)". f. Jika logika 6 yang dibaca maka modul GSM akan memberikan notifikasi ke user dengan SMS : "Info : LAMPU MATI (GANTI LAMPU)",

5. Sebaliknya apabila nilai sensor yang dibaca sudah sesuai dengan yang diprogramkan maka mikrokontroler tidak akan memerintahkan modul GSM untuk mengirim notifikasi ke user.

\section{C.2 Diagram Alir Pengecekan LPJU}

Diagram alir pada saat melakukan monitoring LPJU ditunjukkan seperti Gambar 11.

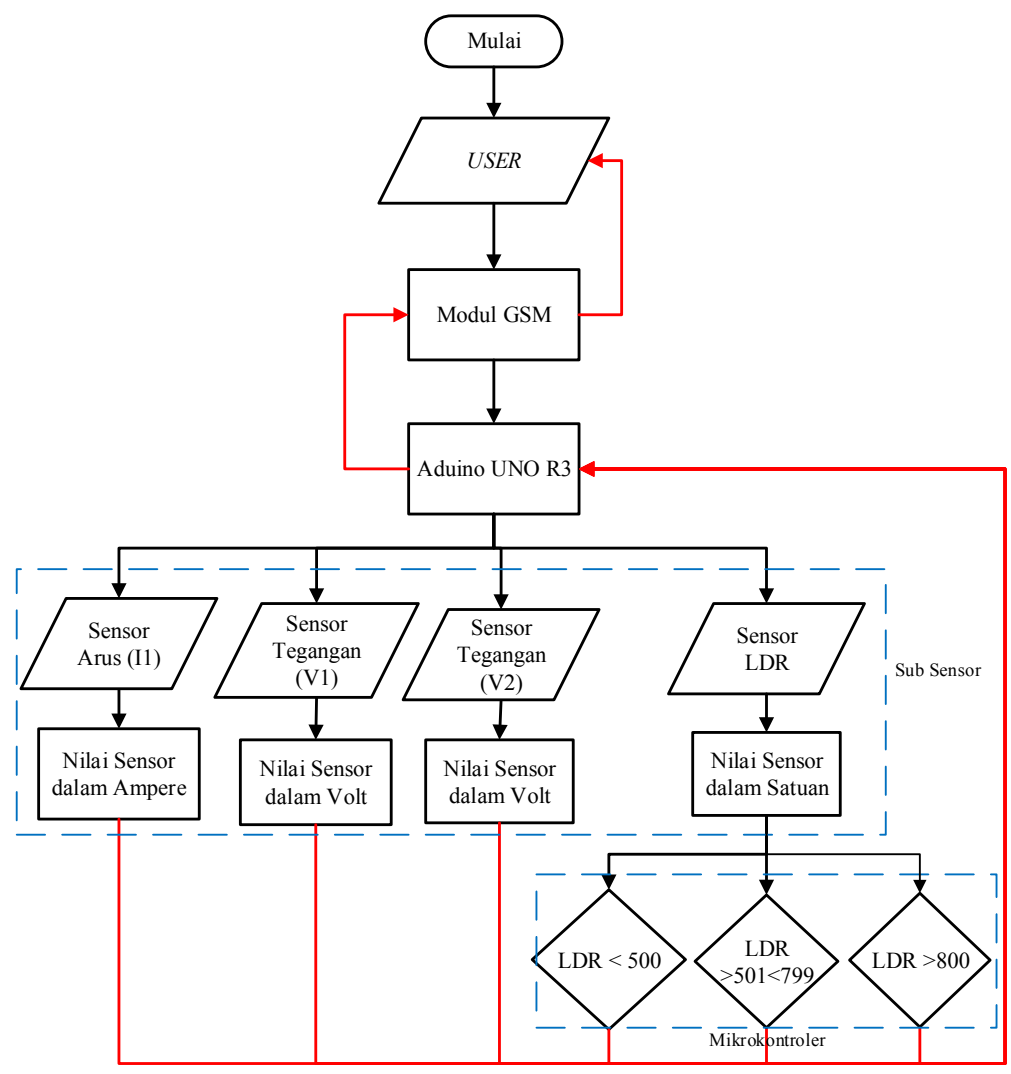

Gambar 11.Diagram alir pengecekan LPJU

Dari gambar 11 dapat dilihat alur program kedua dari rancang bangun alat monitoring kerusakan LPJU :

1. User memberikan perintah SMS dengan kode "CEK LPJU” ke modul GSM, pada modul GSM, SMS yang dikirimkan harus sesuai dengan kode yang diprogramkan, kemudian modul GMS akan memberikan perintah ke mikrokontroler untuk menggolah nilai-nilai yang dibaca pada setiap sensor, misalnya :

a. Besaran nilai yang dibaca oleh sensor tegangan 1 dan sensor tegangan 2 akan langsung dikirim oleh modul GSM ke user dengan notifikasi besaran nilai yang dibaca sensor tegangan.

b. Besaran nilai yang dibaca oleh sensor arus akan langsung dikirim oleh modul GSM ke user dengan notifikasi besaran nilai yang dibaca sensor arus.

c. Jika nilai yang dibaca oleh sensor $\operatorname{LDR}>800$, Maka modul GSM akan memberikan notifikasi ke user dengan SMS "Mati".

d. Jika nilai yang dibaca oleh sensor LDR $>501<$ 799, Maka modul GSM akan memberikan notifikasi ke user dengan SMS "Redup".

e. Jika nilai yang dibaca oleh sensor LDR $<500$, Maka modul GSM akan memberikan notifikasi ke user dengan SMS “Terang”.

\section{HASIL DAN PEMBAHASAN}

\section{A. Hasil Perancangan}

Sistem monitoring kerusakan LPJU merupakan suatu alat yang nantinya dapat digunakan untuk memudahkan 
petugas dalam melaksanakan tugasnya seperti mengetahui terjadinya gangguan dan memudahkan melakukan pengecekan keadaan LPJU. Alat ini akan beroperasi secara otomatis pada waktu yang sudah diatur sebelumnya, misalnya dari jam 19.00 sampai jam 05.00 apabila dari rentan jam yang sudah ditentukan lampu penerangan jalan mengalami gangguan seperti lampu padam yang diakibatkan PLN mati, lampu padam yang diakibatkan kabel LPJU putus, lampu padam yang diakibatkan lampu rusak, dan lampu redup yang diakibatkan terjadinya drop tegangan, lampu redup yang diakibatkan karena umur lampu, serta dari jam 07.00 sampai jam 17.00 ada gangguan seperti lampu penerangan jalan hidup maka alat ini akan secara otomatis mengirimkan notifikasi berupa SMS ke petugas (user) dengan spesifikasi kerusakannya.

Alat ini juga bisa dioperasikan pada saat diperlukan untuk melakukan pengecekan keadaan lampu penerangan jalan dengan cara mengirimkan SMS ke alat dengan kode atau pesan yaitu "CEK LPJU" nanti alat ini akan melakukan pengecekan keadaan LPJU tersebut. SMS tersebut dikirim ke alat yang terpasang pada titik LPJU sesuai dengan nomor yang telah dipasangkan pada alat monitoring kerusakan LPJU. Alat yang dirancang akan dipasang pada setiap titik LPJU.

Gambar realisasi perancangan LPJU ditunjukkan pada Gambar 12, 13, 14, dan 15.

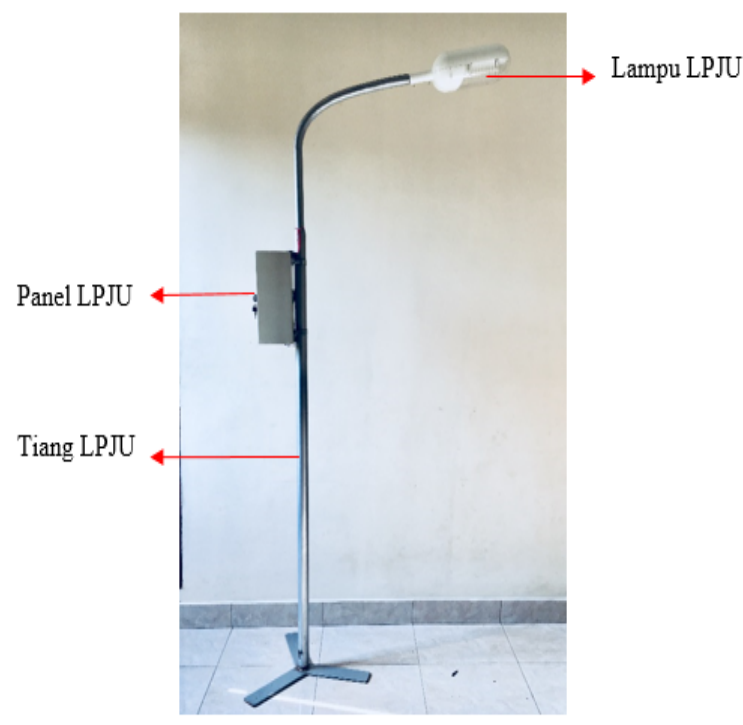

Gambar 12. Realisasi hasil perancangan LPJU

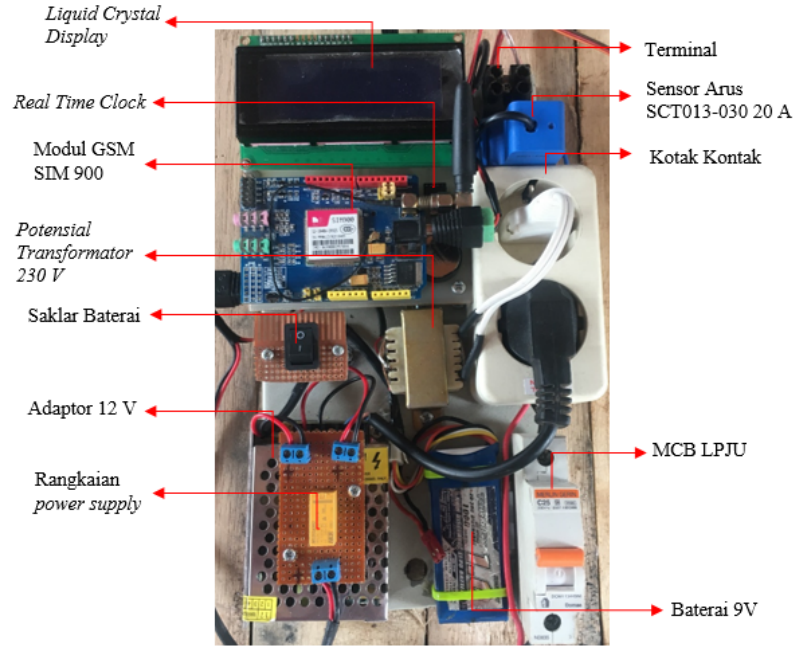

Gambar 13. Realisasi hasil perancangan pada panel LPJU

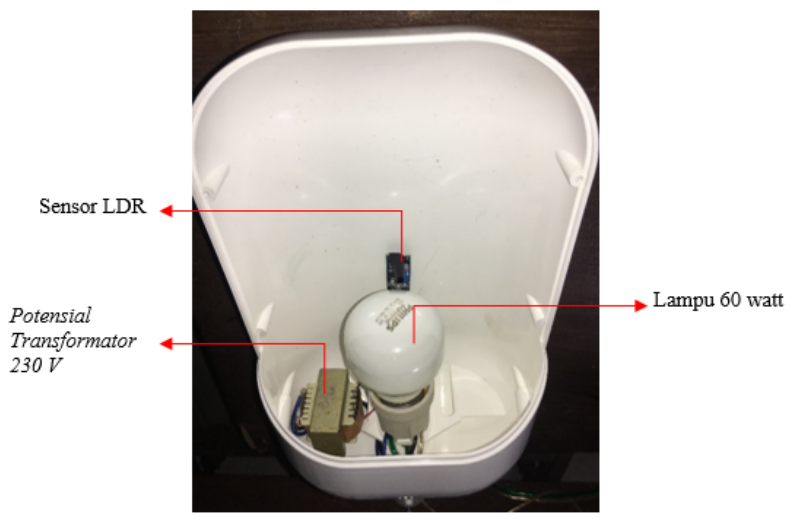

Gambar 14. Realisasi hasil perancangan pada chasing lampu

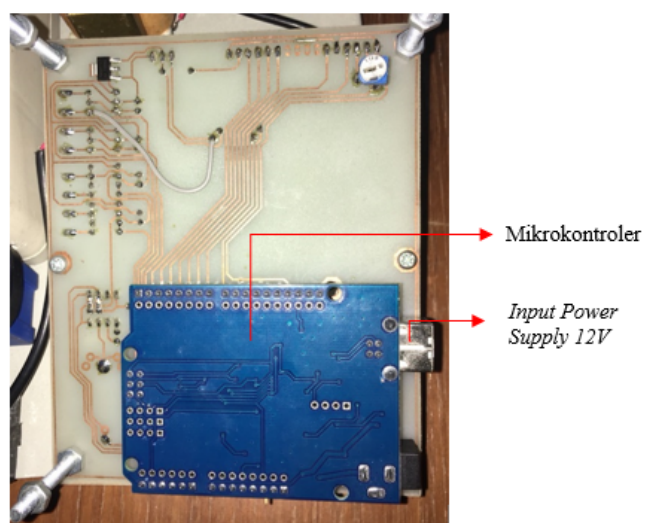

Gambar 15. Realisasi hasil perancangan tampak bawah PCB

\section{B. Pembahasan Keseluruhan Sistem}

Sistem monitoring kerusakan LPJU dengan notifikasi SMS bertujuan untuk menguji keseluruhan sub sistem pada sistem. Terdapat sub sensor tegangan yang akan memberi informasi tentang tegangan yang mengalir pada output meteran PLN dan input lampu, sub sensor arus yang akan memberi informasi tentang nilai arus yang mengalir 
pada LPJU, sub sensor LDR yang akan memberi informasi keadaan pencahayaan lampu, sub RTC yang akan memerintahkan informasi waktu akan untuk memberi keputusan kepada modul IComSat V1.1-SIM900 Shield for Arduino untuk mengirimkan informasi akan keadaan sistem LPJU ke bagian petugas operasi dan pemeliharaan (user) dan sub modul IComSat V1.1-SIM900 Shield for Arduino yang nantinya merintahkan mikrokontroler untuk mengolah pembacaan dari setiap sensor yang kemudian data tersebut dikirim kembali ke user. Pengujian keseluruahan sistem ini menggunakan simulasi dengan membuat satu tiang LPJU dengan dimensi kecil, satu lampu penerangan, dan panel sumber LPJU. Adapun kondisi-kondisi yang diujikan adalah sebagai berikut.

\section{B.1. Lampu padam yang diakibatkan sumber PLN mati}

Pada pengujian mengirim notifikasi lampu padam yang diakibatkan oleh sumber PLN mati menggunakan lampu 60 watt dengan pembacaan dari kedua sensor tegangan di bawah 50 Volt, dan pembacaan nilai sensor LDR diatas 800 bit, maka mikrokontroler akan memerintahkan modul IComSat V1.1-SIM900 Shield for Arduino untuk mengirimkan notifikasi ke user, ditunjukkan seperti pada Gambar 16 dan Gambar 17.

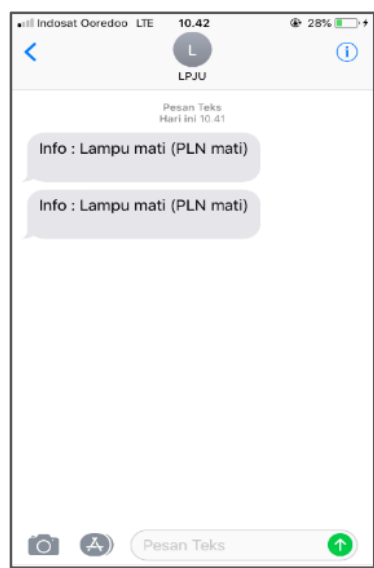

Gambar 16. Notifikasi SMS lampu mati diakibatkan sumber PLN mati

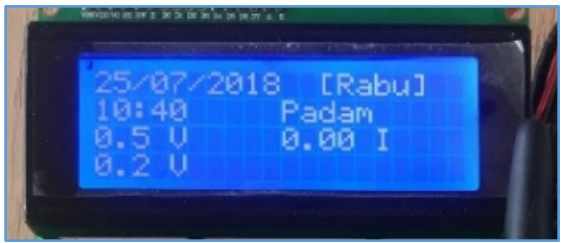

Gambar 17.Tampilan lampu mati diakibatkan sumber PLN mati pada LCD

\section{B.2. Lampu padam yang diakibatkan kabel LPJU putus}

Pada pengujian mengirim notifikasi lampu padam yang diakibatkan oleh kabel LPJU putus menggunakan lampu 60 watt dengan pembacaan dari sensor tegangan satu diatas 200 Volt, dan sensor tegangan dua di bawah 50 Volt, dan pembacaan nilai sensor LDR di atas 800 bit, maka mikrokontroler akan memerintahkan modul
IComSat V1.1-SIM900 Shield for Arduino untuk mengirimkan notifikasi ke user, ditunjukkan seperti pada Gambar 18 dan Gambar 19.

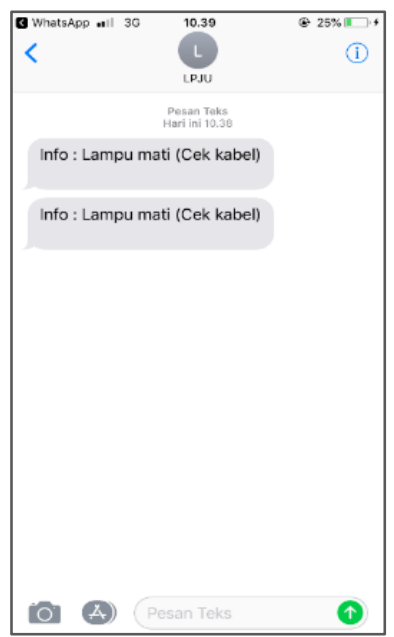

Gambar 18. Notifikasi lampu mati diakibatkan kabel LPJU putus

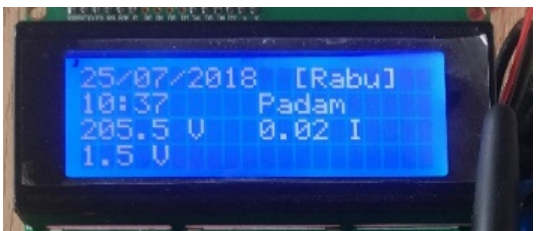

Gambar 19.Tampilan lampu mati diakibatkan kabel LPJU putus pada LCD

\section{B.3. Lampu padam yang diakibatkan lampu rusak}

Pada pengujian mengirim notifikasi lampu padam yang diakibatkan oleh lampunya rusak dengan pembacaan dari kedua sensor tegangan diatas 200 Volt, dan pembacaan nilai sensor LDR diatas 800 bit, maka mikrokontroler akan memerintahkan modul IComSat V1.1-SIM900 Shield for Arduino untuk mengirimkan notifikasi ke user, ditunjukkan seperti pada Gambar 20 dan Gambar 21.

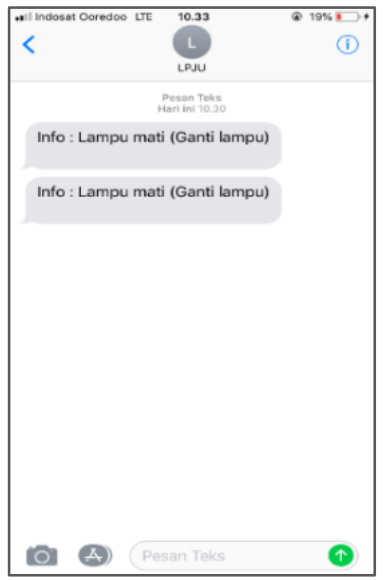

Gambar 20. Notifikasi lampu mati diakibatkan lampu rusak 


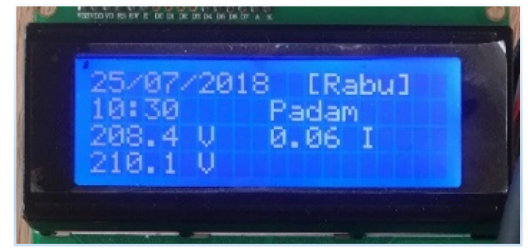

Gambar 21.Tampilan lampu mati diakibatkan lampu rusak pada LCD

\section{B.4. Lampu redup yang diakibatkan drop tegangan dari PLN}

Pada pengujian mengirim notifikasi lampu redup yang diakibatkan oleh drop tegangan dari PLN dengan pembacaan dari kedua sensor tegangan di bawah 200 Volt, dan pembacaan nilai sensor LDR 501 bit sampai 799 bit, maka mikrokontroler akan memerintahkan modul maka modul IComSat V1.1-SIM900 Shield for Arduino akan mengirimkan notifikasi ke user, ditunjukkan seperti pada Gambar 22 dan Gambar 23.

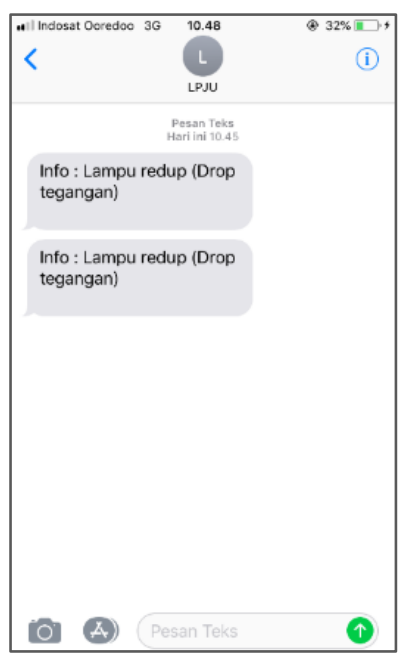

Gambar 22. Notifikasi lampu redup diakibatkan drop tegangan

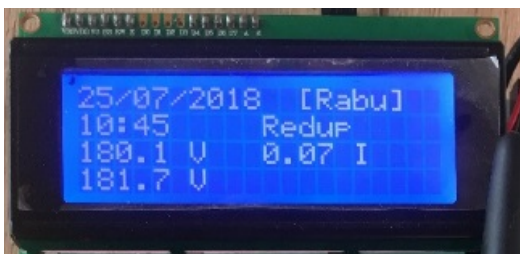

Gambar 23. Tampilan lampu redup diakibatkan drop tegangan pada LCD

\section{B.5. Lampu redup yang diakibatkan umur lampu}

Pada pengujian mengirim notifikasi lampu padam yang diakibatkan oleh umur lampu dengan pembacaan dari kedua sensor tegangan diatas 200 Volt, dan pembacaan nilai sensor LDR 501 bit sampai 799 bit, maka mikrokontroler akan memerintahkan modul maka modul IComSat V1.1-SIM900 Shield for Arduino akan mengirimkan notifikasi ke user, ditunjukkan seperti pada Gambar 24 dan Gambar 25.

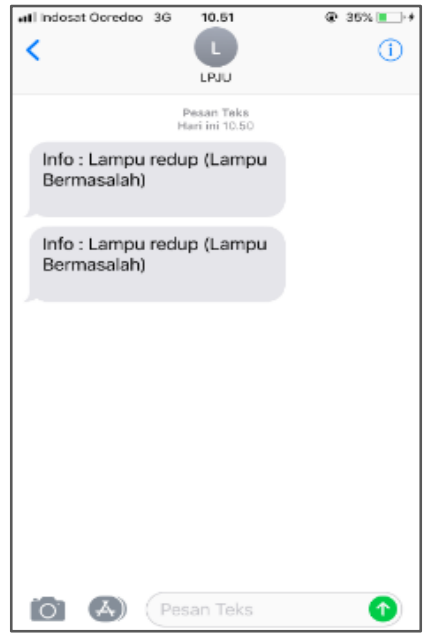

Gambar 24. Notifikasi lampu redup diakibatkan umur lampu

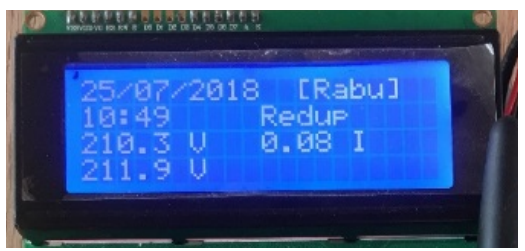

Gambar 25. Tampilan lampu redup diakibatkan umur lampu pada LCD

\section{B.6. Pengujian berdasarkan lampu hidup pada siang hari}

Pada pengujian mengirim notifikasi saat lampu hidup pada siang hari dengan pembacaan dari kedua sensor tegangan di atas 200 Volt, dan pembacaan nilai sensor LDR dibawah 400 bit, maka mikrokontroler akan memerintahkan modul IComSat V1.1-SIM900 Shield for Arduino untuk mengirimkan notifikasi ke user, ditunjukkan seperti pada Gambar 26 dan Gambar 27

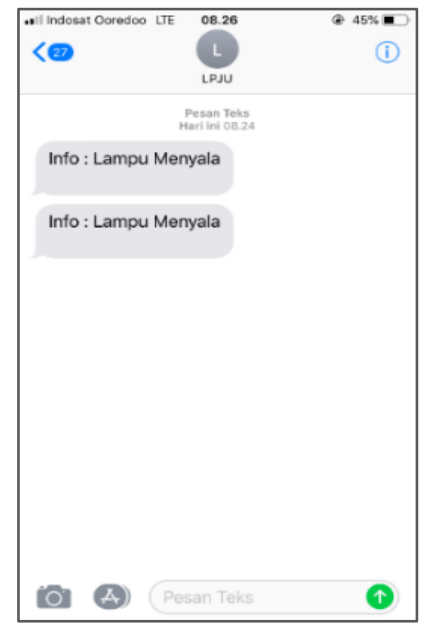

Gambar 26. Notifikasi lampu hidup saat siang hari 


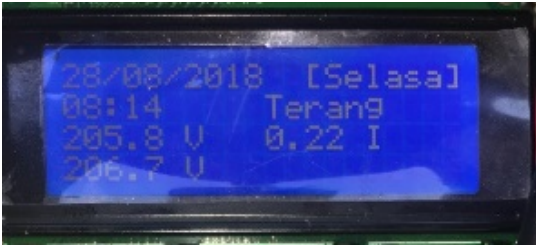

Gambar 27. Tampilan lampu hidup saat siang hari pada LCD

\section{B.7. Pengujian berdasarkan kondisi LPJU}

Pada pengujian berdasarkan monitoring LPJU dengan menggunakan lampu 60 watt ini terlebih dahulu user mengirimkan SMS sesuai kode "CEK LPJU” ke alat, kode yang dikirim oleh user akan diverifikasi telebih dahulu oleh modul IComSat V1.1-SIM900 Shield for Arduino, kemudian modul memerintahkan mikrokontroler untuk mengolah nilai yang dibaca oleh sensor-sensor yang dipasang pada alat. Kemudian nilai yang sudah diolah oleh mikrokontroler kemudian akan dikirim kembali ke user seperti ditunjukkan pada Gambar 28, 29, 30, 31, 32, dan 33.

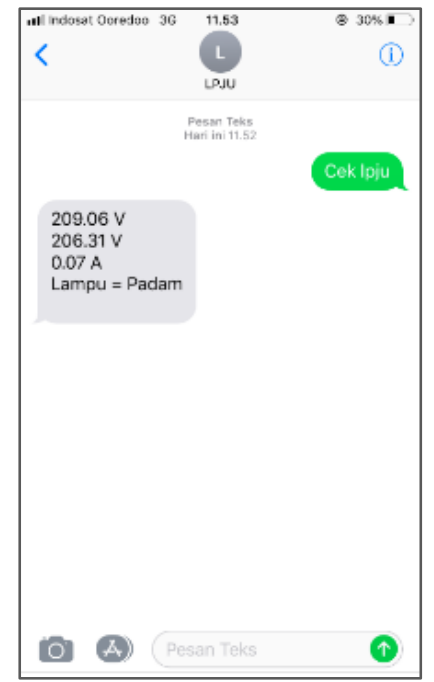

Gambar 28. Notifikasi saat pengecekan LPJU dalam kondisi lampu mati

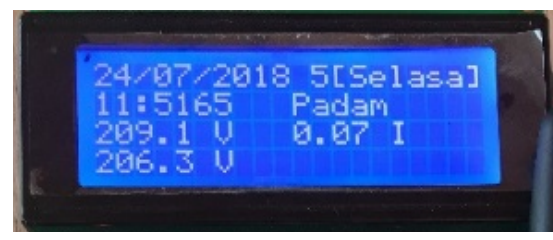

Gambar 29.Tampilan saat pengecekan lampu mati pada LCD

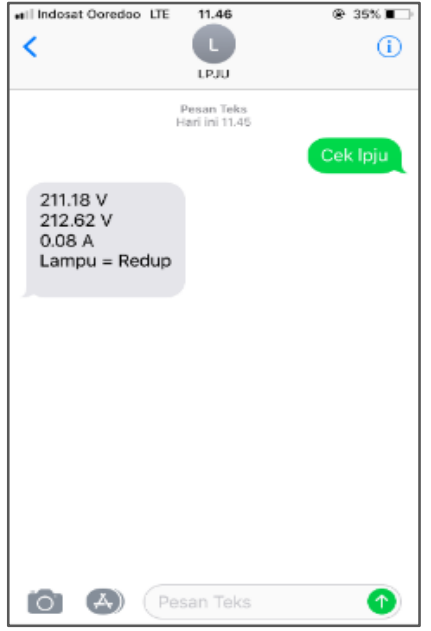

Gambar 30. Notifikasi saat pengecekan LPJU dalam kondisi lampu redup

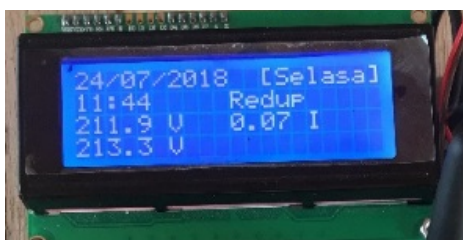

Gambar 31. Tampilan saat pengecekan lampu redup pada LCD

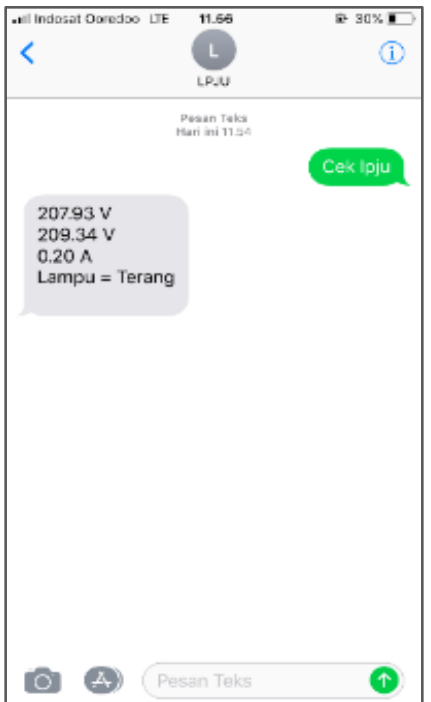

Gambar 32. Notifikasi saat pengecekan dalam kondisi lampu terang

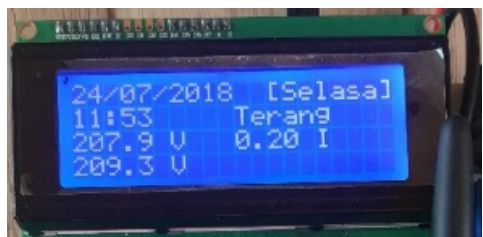

Gambar 33.Tampilan saat pengecekan lampu terang pada LCD 


\section{V.KESIMPULAN}

Alat monitoring yang dirancang telah dapat mengirimkan notifikasi melalui SMS secara otomatis mengenai status atau informasi adanya gangguan pada sistem LPJU seperti lampu padam yang diakibatkan sumber PLN mati, lampu padam yang diakibatkan kabel LPJU putus, lampu padam yang disebabkan lampu rusak, lampu redup yang diakibatkan drop tegangan, lampu redup yang diakibatkan umur lampu, dan lampu hidup pada saat siang hari. Petugas juga dapat melakukan pengecekan secara langsung untuk memastikan lagi keadaan LPJU dengan mengirimkan SMS sesuai format yang sudah diprogramkan pada mikrokontroler dan alat monitoring akan memberikan informasi tentang keadaan LPJU.

Prototipe dari alat monitoring kerusakan LPJU berbasis mikrokontroler dengan notifikasi SMS ini dapat dikembangkan lebih lanjut dengan menambahkan mekanisme pengiriman SMS informasi tentang spesifikasi kerusakan pada LPJU yang langsung menuju server pusat, tidak melalui petugas bagian operasi dan pemeliharaan, sehingga sistem menjadi lebih efektif dan efisien. Selain itu, dapat dilakukan pemanfaatan atau penambahan modul wireless (WiFi) untuk memudahkan pengiriman data dalam pemantauan kerusakan LPJU berbasis jaringan.

\section{DAFTAR PUSTAKA}

[1] E. Ihsanto dan M. Dawud, "Sistem Monitoring Lampu Penerangan Jalan Umum Menggunakan Mikrokontroler Arduino dan Sensor LDR dengan Notifikasi SMS," $J$. Teknol. Elektro, vol. 7, no. 2, pp. 101-105, 2016.

[2] A. Fitriandi, E. Komalasari, dan H. Gusmedi, "Rancang Bangun Alat Monitoring Arus dan Tegangan Berbasis Mikrokontroler dengan SMS Gateway," J. Rekayasa dan Teknol. Elektro, vol. 10, no. 2, pp. 87-98, 2016.

[3] Sutono, "Perancangan Sistem Aplikasi Otomatis Lampu Penerangan Menggunakan Sensor Gerak dan Cahaya Berbasis Arduino UNO (ATEMEGA 328)," Maj. Ilm. Unikom, vol. 12, no. 2, pp. 223-232, 2014.

[4] M. Syahwil, Panduan Mudah Simulasi dan Praktek Mikrokontroler Arduino. Yogyakarta: Andi Offset, 2014.

[5] B. Mismail, Rangkaian Listrik, Jilid Kedu. Bandung: Penerbit ITB, 1997.

[6] It. Studio, "IComSat v1.1 - SIM900 GSM/GPRS shield." [Online]. Available: https://arduino.ua/docs/icomsat_DS1.2.pdf.

[7] M. Syahwil, Panduan Mudah Belajar Arduino Menggunakan Simulasi Proteus. Yogyakarta: Andi Offset, 2017. 